\title{
Comparison of Blood Gas Analysis Results: Liquid Sodium Heparin Versus Dry Lithium Heparin
}

\author{
Kan Gazı Analiz Sonuçlarının Karşılaştırılması: Kuru \\ Lityum Heparine Karşı Sıvı Sodyum Heparin
}

\section{Özgün Araştırma Research Article}

\section{Alındığı tarih: 25.12 .2017 \\ Kabul tarihi: 16.01.2019 \\ Online Yayın tarihi: 31.12.2019}

Turgay Yılmaz Kilic Tepecik Eğitim ve Araştırma Hastanesi, Acil Tıp Kliniği, Izmir - Türkiye

turgayyilmaz.kilic@gmail.com ORCiD: 0000-0002-3494-5120

S. Sezik 0000-0002-0870-1050 Odemis Devlet Hastanesi, Acil Servis, Izmir, Türkiye

H. Idil 0000-0001-5828-3224 Tepecik Eğitim ve Araştırma Hastanesi, Acil Tip Kliniği, Izmir, Türkiye

Cite as: Sezik S, Kilic TY, Idil H. Comparison of blood gas analysis results: liquid sodium heparin versus dry lithium heparin. Tepecik Eğit. ve Araşt. Hast. Dergisi. 2019;29(3):280-4.

\author{
Savas Sezik $\odot$, Turgay Yılmaz Kilic $\odot$, Hasan Idil $\odot$
}

\section{ABSTRACT}

Objective: In this study, we aimed to compare blood gas analysis results obtained with injection syringes washed with liquid sodium heparin and syringes containing dry lithium heparin. Additionally, it was also aimed to investigate the compliance of blood gas parameters with laboratory results.

Method: This prospective study was performed of patients who underwent complete blood count and glucose, urea, creatinine, electrolyte levels along with venous blood gas analysis due to any cause in emergency department admission. Blood samples were transferred to blood gas syringe containing dry lithium heparin and plastic syringe washed with liquid sodium heparin. Blood gas analyses were performed within five minutes after venous blood gas samples were taken. The demographic data of the patients, blood gas analysis results obtained with injection syringes washed with liquid sodium heparin and syringes containing dry lithium heparin and serum hemoglobin, sodium, potassium, calcium and glucose levels were evaluated.

Results: A hundred patients were included in the study. 52 patients were male (52\%) and the mean age was $60.3 \pm 17.1$ years. The blood gas analysis results obtained by liquid and dry-heparin syringes were found to be correlated with each other except calcium values. Intraclass correlation coefficient of $\mathrm{pH}$, partial pressure of carbon dioxide and partial pressure of oxygen parameters from blood gas analysis results obtained with liquid and dry heparin syringes were found to be high $(0.989,0.933,0.948$; respectively).

Conclusion: There is no significant advantage of dry lithium heparin blood gas syringes over liquid sodium heparin washed syringes.

Keywords: Dry lithium heparin syringe, liquid sodium heparin syringe, blood gas analysis

öz

Amaç: Bu çalışmada, sıvı sodyum heparinle yıkanmış enjektörler ve kuru lityum heparin içeren enjektörler ile çalışılan kan gazı analiz sonuçlarını karşılaştırmayı amaçladık. Ayrıca, kan gazı parametrelerinin laboratuvar sonuçları ile uyumunun araştırılması da hedeflenmiştir.

Yöntem: Bu prospektif çalıșma acil servis başvurusunda tam kan sayımı ve glukoz, üre, kreatinin, elektrolit düzeyleri ile birlikte herhangi bir nedenden dolayı venöz kan gazı analizi yapılan hastalar ile yapıldı. Kan örnekleri, kan gazı analizi için kuru lityum heparin içeren enjektöre ve sıvı sodyum heparin ile yıkanmış plastik enjektöre aktarıldı. Venöz kan gazı örneği alındıktan sonraki ilk 5 dk. içerisinde kan gazı analizi yapıldı. Hastaların demografik verileri, kuru lityum heparin içeren enjektör ve sıvı sodyum heparin ile yıkanmış enjektörle elde edilen kan gazı analiz sonuçları ve serum hemoglobin, sodyum, potasyum, kalsiyum ve glukoz seviyeleri değerlendirildi.

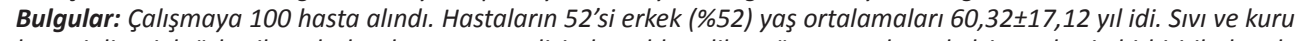
heparinli enjektörler ile çalışılan kan gazı analizinden elde edilen tüm sonuçların kalsiyum hariç birbiri ile korele olduğu saptandı. Sıvı ve kuru heparinli enjektörler ile çalısıllan kan gazı analizinden elde edilen ph, parsiyel karbondioksit basıncı ve parsiyel oksijen basıncı parametreleri için sınıf içi korelasyon katsayısı yüksek bulundu (sırasıyla $0,989,0,933,0,948)$.

Sonuç: Katı lityum heparinli kan gazı enjektörlerinin sıvı sodyum heparin içeren enjektörlere herhangi bir üstünlüğü yoktur.

Anahtar kelimeler: Katı lityum heparinli enjektör, sıvı sodyum heparinli enjektör, kan gazı analizi

(C) Telif hakkı T.C. Sağlık Bakanlığı İzmir Tepecik Eğit. ve Araşt. Hastanesi. Logos Tıp Yayıncılık tarafindan yayınlanmaktadır. Bu dergide yayınlanan bütün makaleler Creative Commons Attf-GayriTicari 4.0 Uluslararası Lisansı ile lisanslanmıştr.

(c) Copyright Association of Publication of the T.C. Ministry of Health izmir Tepecik Education and Research Hospital. This journal published by Logos Medical Publishing.

Licenced by Creative Commons Attribution-NonCommercial 4.0 International (CC BY-NC 4.0) 


\section{INTRODUCTION}

The use of fast and reliable tests in emergency departments (ED) are very important for patient management, early diagnosis and treatment. Blood gas analysis that is used for this purpose, provides important information for the evaluation of critical patients in EDs. The main indications for arterial blood gas analysis are short term evaluations of the patient's ventilation, general metabolic status, and acid-base and electrolyte balance ${ }^{(1-3)}$. Using arterial blood samples in blood gas analysis is accepted as the golden standard. However, due to the fact that drawing arterial blood sample is more difficult, painful and risky with regards to complications, venous blood gas analysis is often preferred ${ }^{(3)}$.

Studies on blood gas have demonstrated that the results may vary based on used anticoagulant's grade, quantity, used syringes, storage duration, air bubbles in the blood, formation of small clots (microcloting), and temperature changes ${ }^{(2,3)}$. Today, the anticoagulant that is routinely used in blood gas analysis is heparin ${ }^{(4)}$. Due to the high costs of syringes containing dry heparin and the continuation of traditional methods, syringes washed with liquid heparin are used more frequently ${ }^{(5,6)}$.

In this study, we aimed to compare blood gas analysis results obtained with injection syringes washed with liquid sodium heparin and syringes containing dry lithium heparin. Additionally, it was also aimed to investigate the compliance of blood gas parameters with laboratory results.

\section{MATERIAL and METHODS}

This prospective study was conducted between August to September of 2014 in a tertiary urban ED with an annual admission rate of nearly 180.000 . Prior to the study, local ethics committee approval was obtained, and patient consent was obtained to participate in the study. Patients who underwent complete blood count and glucose, urea, creatinine, electrolyte levels (sodium, potassium, calcium) along with venous blood gas analysis due to any cause (acute renal failure, drug overdose, respiratory distress, hyperglisemia, seizures, sepsis, etc.) in ED admission were taken into the study on a voluntary basis.

Blood samples taken from the antecubital venous were transferred to blood gas syringe containing 72 IU dry lithium heparin (Plasti-med blood gas syringe 2 ml. Plastik Medikal Ür. San. Tic. Ltd. Sti. İstanbulTürkiye)R and plastic syringe washed with liquid sodium heparin (Ayset sterile syringe $2 \mathrm{ml}$. Ayset Aş. Adana/Turkey) ${ }^{\circledR}$, one milliliter each. The procedure of washing with liquid heparin was performed after the syringe was washed with heparin (Vasparin $25000 \mathrm{IU} / 5 \mathrm{ml}$ Heparin Sodyum Mepar Illaç Sanayi AŞ. İstanbul/Turkey) ${ }^{\circledR}$ with the syringe end facing downwards, and by moving the piston back and forth three times. In addition, venous blood samples taken from patients were sent to the biochemistry laboratory for hemoglobin ( $\mathrm{Hgb})$, sodium $\left(\mathrm{Na}^{+}\right)$, potassium $\left(\mathrm{K}^{+}\right)$, calcium $\left(\mathrm{Ca}^{+}\right)$and glucose parameters.

Washing the syringes with liquid heparin, taking the blood samples and blood gas analyses were performed by three emergency medicine specialists. In this study, demographic data of the patients, blood gas analysis results $\mathrm{(pH}$, partial pressure of carbon dioxide $\left(\mathrm{PaCO}_{2}\right)$, partial pressure of oxygen $\left(\mathrm{PaO}_{2}\right)$, bicarbonate $\left(\mathrm{HCO}_{3}\right)$, base excess $(\mathrm{BE})$, hematocrit $(\mathrm{Hct})$, $\mathrm{Hgb}$, oxygen saturation $\left(\mathrm{SatO}_{2}\right), \mathrm{Na}^{+}, \mathrm{K}^{+}, \mathrm{Ca}^{+}$, glucose, lactate values) and additionally measured serum $\mathrm{Hgb}, \mathrm{Na}^{+}, \mathrm{K}^{+}, \mathrm{Ca}^{+}$and glucose results were statistically evaluated.

Blood gas analyses were performed in a Siemens Rapid 1200 blood Gas Analyzer Product Specification ${ }^{\circledR}$ device within five minutes after venous blood gas samples were taken. Hgb values were measured in a Cell Dyn 3700 Blood Measurement 
Device $\mathrm{Abbott}^{\circledR}$, and $\mathrm{Na}, \mathrm{K}$, glucose levels were measured in a Olympus AU 640 Beckman CoulterR device in the biochemistry laboratory.

\section{Statistical Analysis}

Statistical analysis was performed using IBM SPSS software package program (v.20.0 SPSS Inc., Chicago IL. USA). Correlation between the parameters were investigated with Shapiro-Wilk Test, and nonparametric tests were used for non-normal distributions. Parametric data were expressed as number of observations and percentage (\%), qualitative data were expressed as mean \pm standard deviation or median (minimum-maximum). For non-parametric correlations Spearman Correlation Analysis was used. In the study, data were evaluated with BlantAltman Analysis with the assistance of Med-Calc software, for comparison based on laboratory measurement results. In the analyses, $\mathrm{p}<0.05$ was considered significant.

\section{RESULTS}

A total of 105 patients were taken into the study. A total of 5 patients, who were issued a warning during the blood sample measurements; 3 in the blood gas device, and 2 in the blood count device, were excluded from the study. Ultimately, results of 100 patients were evaluated. 52 patients were male (52\%), and the mean age was $60.3 \pm 17.1$ year.

Range, mean, and ICC (intraclass correlation coefficient) values of $\mathrm{pH}, \mathrm{PaCO}_{2}, \mathrm{PaO}_{2}, \mathrm{HCO}_{3}, \mathrm{BE}, \mathrm{Hct}, \mathrm{Hgb}$, $\mathrm{SatO}_{2}, \mathrm{Na}^{+}, \mathrm{K}^{+}, \mathrm{Ca}^{+}$, glucose, lactate measurements obtained from blood gas analysis performed with liquid and dry heparin syringes are shown in Table 1. In the Bland-Altman analysis $\mathrm{Hgb}, \mathrm{Na}^{+}, \mathrm{K}^{+}$, glucose values obtained from blood gas analyses performed with liquid and dry heparin syringes were compared based on laboratory results. According to the BlandAltman analysis, mean agreement difference $\left(\mathrm{d}^{-}\right)$ and limits of agreement are shown in Table 2.
Table 1. Comparison of liquid and dry lithium heparin sodium heparin blood gas results.

\begin{tabular}{lccccc}
\hline & $\begin{array}{c}\text { Liquid } \\
\text { Heparin } \\
\text { (Range) }\end{array}$ & $\begin{array}{c}\text { Dry } \\
\text { Heparin } \\
\text { (Range) }\end{array}$ & $\begin{array}{c}\text { Liquid } \\
\text { Heparin } \\
\text { (Mean } \pm S \mathrm{SD})\end{array}$ & $\begin{array}{c}\text { Dry } \\
\text { Heparin } \\
\text { (Mean } \pm \text { SD) }\end{array}$ & ICC \\
\hline $\mathrm{pH}$ & $6.96-7.55$ & $6.95-7.53$ & $7.38 \pm 0.08$ & $7.39 \pm 0.08$ & 0.989 \\
$\mathrm{PaCO}_{2}$ & $24.2-70.2$ & $24.1-71.9$ & $39.6 \pm 7.1$ & $40.7 \pm 7.8$ & 0.948 \\
$\mathrm{PaO}_{2}$ & $15.2-97.0$ & $16.5-74.8$ & $35.3 \pm 13.2$ & $36.4 \pm 11.9$ & 0.933 \\
$\mathrm{HCO}_{3}$ & $8.0-38.9$ & $8.0-40.1$ & $23.3 \pm 4.6$ & $24.3 \pm 5.2$ & 0.962 \\
$\mathrm{BE}$ & $0.0-22.3$ & $0.0-22.2$ & $3.4 \pm 3.9$ & $3.6 \pm 3.9$ & 0.971 \\
$\mathrm{Hct}$ & $12.0-59.0$ & $16.0-58.0$ & $35.6 \pm 9.1$ & $36.7 \pm 8.9$ & 0.959 \\
$\mathrm{Hgb}$ & $4.2-20.1$ & $5.3-19.6$ & $12.1 \pm 3.8$ & $12.9 \pm 3.0$ & 0.959 \\
$\mathrm{SatO}_{2}$ & $20.0-98.5$ & $19.7-95.0$ & $62.8 \pm 18.8$ & $65.1 \pm 18.5$ & 0.941 \\
$\mathrm{Na}^{+}$ & $125.9-164.3$ & $124.1-164.6$ & $140.5 \pm 4.6$ & $140.2 \pm 4.7$ & 0.978 \\
$\mathrm{~K}^{+}$ & $2.5-6.1$ & $2.7-6.4$ & $3.9 \pm 0.8$ & $4.2 \pm 0.7$ & 0.879 \\
$\mathrm{Ca}^{+}$ & $0.3-1.4$ & $0.7-1.4$ & $0.8 \pm 0.2$ & $1.9 \pm 0.1$ & 0.099 \\
$\mathrm{Glucose}^{+}$ & $51.0-409.0$ & $58.0-419.0$ & $137.9 \pm 67.7$ & $146.4 \pm 71.9$ & 0.995 \\
Lactat $^{+}$ & $0.5-8.2$ & $0.4-8.1$ & $1.9 \pm 1.5$ & $2.1 \pm 1.6$ & 0.993 \\
\end{tabular}

Abbreviations: ICC: Interclass corelation, $\mathrm{PaCO}_{2}$ : Partial pressure of carbon dioxide, $\mathrm{PaO}_{2}$ : Partial pressure of oxygen, $\mathrm{HCO}_{3}$ : Bicarbonate, $\mathrm{BE}$ : Base excess, Hct: Hematocrit, $\mathrm{Hg}$ : Hemoglobin, $\mathrm{SatO}_{2}$ : Oxygen saturation, $\mathrm{Na}^{+}$: Sodium, $\mathrm{K}^{+}$: Potassium, $\mathrm{Ca}^{+}$: Calcium.

Table 2. Bland-Altman analysis based on blood gas and laboratory results of blood compliance with limits and compliance differences mean (d ${ }^{-}$.

\begin{tabular}{lccc}
\hline & $\left.\mathbf{( d}^{-}\right)$ & \multicolumn{2}{c}{ $\pm 1.96 \mathrm{Cl}$} \\
\hline Dry heparin Hgb- Serum Hgb & 1.03 & 1.16 & 0.90 \\
Liquid heparin Hgb- Serum Hgb & 1.00 & 1.20 & 0.79 \\
Dry heparin $\mathrm{Na}^{+}$- Serum $\mathrm{Na}^{+}$ & 0.99 & 1.03 & 0.95 \\
${\text { Liquid heparin } \mathrm{Na}^{+} \text {- Serum } \mathrm{Na}^{+}}^{\text {Dry heparin } \mathrm{K}^{+}-\text {Serum } \mathrm{K}^{+}}$ & 0.98 & 1.02 & 0.94 \\
Liquid heparin $\mathrm{K}^{+}$- Serum $\mathrm{K}^{+}$ & 1.06 & 1.33 & 0.79 \\
Dry heparin glucose - Serum glucose & 0.88 & 1.13 & 0.63 \\
Liquid heparin glucose - Serum glucose & 0.95 & 1.29 & 0.60 \\
& 1.16 & 1.60 & 0.71 \\
\hline
\end{tabular}

Abbreviations: $\mathrm{Cl}$ : Confidence interval, $\mathrm{Hgb}$ : Hemoglobin, $\mathrm{Na}^{+}$: Natrium, $K^{+}$: Potassium

\section{DISCUSSION}

Blood gas analysis is a commonly used method since it can be performed quickly and provides valuable results. The accuracy of its results are very important because of its direct impact on patient management in many diseases. Blood gas analysis can be performed with liquid or dry-heparin syringes on arterial or venous blood samples ${ }^{(1,3)}$.

In our study, blood gas analysis results $\left(\mathrm{pH}, \mathrm{PaCO}_{2}\right.$, $\mathrm{PaO}_{2}, \mathrm{HCO}_{3}, \mathrm{BE}, \mathrm{Hct}, \mathrm{Hgb}$, SatO ${ }_{2}, \mathrm{Na}^{+}, \mathrm{K}^{+}$, glucose, lactate) obtained by liquid and dry-heparin syringes were found to be correlated with each other except $\mathrm{Ca}^{+}$values. Moreover, it was observed that $\mathrm{Hgb}, \mathrm{Na}^{+}$, 
$\mathrm{K}^{+}$, and glucose values obtained from two types of syringes were within limits of agreement according to the results obtained from the blood measurement device.

In the manual of Clinical and Laboratory Standards Institute (CLSI), it has been noted that choosing of liquid heparin as the anticoagulant can lead to consequences like dilution, impact due to heparin salts (increasing $\mathrm{Na}+$ level by $3 \mathrm{mmol} / \mathrm{l}$ ), and direct binding of ionized calcium. It has been noted that in the case of the using dry heparin, there will not be a dilution problem, but clot formation may be observed ${ }^{(1)}$.

For blood gas syringes prepared with liquid heparin, using the least amount of heparin to inhibit coagulation gives the most accurate results in the blood gas analysis ${ }^{(7,8)}$. In our study, no coagulation problem related with dry lithium heparin syringes have been observed. In addition, syringe pistons were strongly moved back and forth three times during washing with liquid sodium heparin to reduce the amount of heparin inside the syringe to a minimum, and incorrect measurements were reduced accordingly. Only $\mathrm{Ca}^{+}$levels were affected by this, and measured to be lower than normal.

In our study, ICC of $\mathrm{pH}, \mathrm{PaO}_{2}$ and $\mathrm{PaCO}_{2}$ parameters from blood gas analysis results obtained with liquid and dry heparin syringes were found to be high (0.989, 0.933, 0.948; respectively). Similar studies have demonstrated that there is a correlation between $\mathrm{pH}, \mathrm{PaO}_{2}$ and $\mathrm{PaCO}_{2}$ parameters ${ }^{(9-14)}$. In one of these studies, $\mathrm{PaCO}_{2}$ levels were found to be significantly lower in liquid heparin syringes ${ }^{(11)}$. In another study, although $\mathrm{PaCO}_{2}$ and $\mathrm{PaO}_{2}$ levels were found to be significantly different, they were reported to be within clinically acceptable limits ${ }^{(14)}$.

\section{Limitations}

Low patient number, blood gas analysis being performed only on venous blood sample are limitations in our study. One of the factors that can affect blood gas analysis results is high levels of serum proteins. However, serum protein levels of patients in our emergency department were not checked.

\section{CONCLUSION}

There is no significant advantage of dry lithium heparin blood gas syringes over liquid sodium heparin washed syringes. When cost concerns are takin into account, liquid sodium heparin syringes washed in appropriate conditions can be used for blood gas analysis.

Ethics Committee Approval: Approval from the Ethics Committee of İzmir Katip Çelebi University. (Approval Number: 166, Date: 02/08/2013).

Conflict of Interest: The authors declare that they have no conflict of interest.

Funding: This study has received no financial support.

Informed Consent: Patient consent was obtained to participate in the study.

Etik Kurul Onayı: İzmir Katip Çelebi Üniversitesi Etik Kurulu'ndan onay alınmıştır. (Onay Numarası: 166, Tarih: 02/08/2013).

Çıkar Çatışması: Yazarlar çıkar çatışması olmadığını beyan eder.

Finansal Destek: Bu çalışmaya maddi destek verilmemiştir.

Hasta Onamı: Çalışmaya katılmak için hasta onamı alındı.

\section{REFERENCES}

1. CLSI. Blood gas and Ph analysis and related measurements; approved guideline - second edition. CLSI Document C46-A2. Wayne, PA: Clinical and Laboratory Standards Institute, 2010.

2. Davis MD, Walsh BK, Sittig SE, et al. AARC clinical practice guideline: blood gas analysis and hemoximetry: 2013. Respir Care. 2013;58(10):1694-703. [CrossRef]

3. Baird G. Preanalytical considerations in blood gas analysis. Biochem Med (Zagreb) 2013;23(1):19-27. [CrossRef]

4. Higgins $C$. The use of heparin in preparing samples for blood- 
gas analysis. MLO Med Lab Obs. 2007;39(10):16-8,20;quiz 22-3.

5. Baskın SB, Oray NÇ, Yanturalı S, et al. The comparison of heparinized insulin syringes and safety-engineered blood gas syringes used in arterial blood gas sampling in the ED setting (randomized controlled study). Am J Emerg Med. 2014;32(5):432-7. [CrossRef]

6. Gruber M, Spaeth R, Bechmann V. Heparin release is insufficient in syringes with platelets as heparin source. Clin Chim Acta. 2008;395(1-2):187. [CrossRef]

7. Burnett RW, Covington AK, Fogh-Andersen $\mathrm{N}$, et al. International Federation of Clinical Chemistry (IFCC). Scientific Division. Committee on $\mathrm{pH}$, Blood Gases and Electrolytes. Approved IFCC recommendations on whole blood sampling, transport and storage for simultaneous determination of $\mathrm{pH}$, blood gases and electrolytes. Eur J Clin Chem Clin Biochem. 1995;33(4):247-53.

8. Chhapola V, Kanwal SK, Goyal P, et al. Use of liquid heparin for blood gas sampling in pediatric intensive care unit: $A$ comparative study of effects of varying volumes of heparin on blood gas parameters. Indian J Crit Care Med. 2013;17(6):350-4. [CrossRef]
9. Madi JM, Morais EN, Festugatto JR, et al. Effect of lyophilized and liquid heparin on umbilical cord blood pH measure. Rev. Bras. Ginecol. Obstet. 2003:25(5):371-3. [CrossRef]

10. Çevik A, Çevik N. Sodyum heparin, lityum heparin ve zaman kan gazları ve elektrolitlerin değerlerinde bir değişiklik yapıyor mu? Türk Anest Rean Der Dergisi. 2003;31(1):36-42.

11. Gayed AM, Marino ME, Dolanski EA. Comparison of the effects of dry and liquid heparin on neonatal arterial blood gases. Am J Perinatol. 1992;9(3):159-61. [CrossRef]

12. Madiedo G, Sciacca R, Hause L, et al. Use of syringes containing dry (lyophilized) heparin in sampling blood for $\mathrm{pH}$ measurement and blood-gas analysis. Clin Chem. 1982;28(7):1727-9.

13. Crockett AJ, McIntyre E, Ruffin R, et al. Evaluation of lyophilized heparin syringes for the collection of arterial blood for acid base analysis. Anaesth Intensive Care. 1981;9(1):40-2. [CrossRef]

14. Carter BG, Tibballs J, Hochmann M, et al. A comparison of syringes to collect blood for analysis of gases, electrolytes and glucose. Anaesth Intensive Care. 1994;22(6):698-702. [CrossRef] 